\title{
Performance of Non-State Actors in Provision of Water Services in Arid and Semi-Arid Areas: A case of Kyuso Sub-County, Kenya
}

\author{
Philip K. Mwendwa \\ Kabarak University,School of Education \\ P.O Private Bag-20157, Kabarak, Kenya
}

\begin{abstract}
The study on performance of Non-State actors in provision of water services in arid and semi-arid areas was undertaken in Kyuso Sub-county, Kenya. Data on the performance of Non-State actors including their contribution to water service provision, challenges and measures to improve their performance was collected between January 2020 and December 2020. Questionnaire survey and interview schedules were used to collect data from households, managers of the Community Based Organizations (CBOs) and Non-Governmental Organizations (NGOs) and County government officials. Data collected was analysed using SPSS and Excel software to reveal the trends in water service provision by Non-State actors. The results indicated that Non-State actors have greatly reduced the distance that residents have to travel to access water in the study area to about a kilometre. The study also established that Non-State actors were facing several challenges including poor management structures, poor water infrastructure, low rainfall, inadequate water storage facilities, high water connection fee and vandalism of infrastructure. To mitigate these challenges, the study recommended that the Non-State actors should improve structures of public participation, invest in training the managers of the projects and improve their water storage facilities. The County government should also ensure that there is adequate and frequent supply of water through the Kiambere-Mwingi water pipeline that some of the Non-State actors rely on to supply water to the residents.
\end{abstract}

Keywords: Non-State actors, water service provision, Kyuso Sub-County, Water Access

DOI: $10.7176 / \mathrm{JEES} / 11-11-05$

Publication date: November $30^{\text {th }} 2021$

\section{Introduction}

Access to safe drinking water is important for the attainment of the Sustainable Development Goal 6 (United Nations 2015). However, this is a challenge for many countries in the world since 2.2 billion people lack access to clean drinking water (UNESCO, UN-WATER 2020). In Sub-Saharan Africa, the growing urban population coupled with climate change is posing a major challenge to safe drinking water supply. Approximately $42 \%$ of the population in this region do not have access to clean water (Eberhard 2019).

In Kenya, it is estimated that 9.9 million people, representing $21 \%$ of the total population, draw their drinking water from contaminated surface water sources (UNICEF Kenya 2020). In arid and semi-arid areas, recurrent droughts make access to drinking water a challenge. In most of these areas, communities rely on ground water sources accessed through wells and boreholes, and surface water from water pans and dams (USAID 2019). These water supply structures, however, tend to break due to poor management or overuse in the dry season. The unreliable nature of rainfall in these areas also lead to poor replenishing of the surface water sources, making them to dry after a short period. Additionally, lack of political goodwill, inadequate financial resources and socio-cultural factors have proven to be barriers to adequate supply of water in arid and semi-arid areas (World Health Organization; UN-Water 2014).

Kyuso Sub-County, located in the semi-arid Southeastern Kenya is highly affected by recurrence of droughts that diminish water supply in the area. The main water source in this Sub-County is the seasonal rivers and Kiambere-Mwingi water pipeline. During the dry season, the seasonal rivers dry up making access to safe drinking water difficult (Munyui 2015). It is estimated that $42.3 \%$ of people in this Sub-County access water from streams/rivers while only $9.3 \%$ gain access to water from public taps (Kenya National Bureau of Statistics 2019). In recognition of these challenges, several Non-Governmental Organizations (NGOs) and donors have come up with projects to improve water accessibility. It has been proven that public sector cannot adequately provide water services (Munala 2009). Consequently, several sectoral and institutional reforms have been undertaken, paving the way for participation of Non-State actors in the previously only public service sector (Munala 2009). This study seeks to determine how the Non-State actors have performed in providing water services. 


\section{Description of the Study Area}

\subsection{Location}

Kyuso Sub-County is located in the Southeastern region of Kenya in Kitui County (Figure 2.1). The area lies between latitude $0^{0} 33^{\prime} \mathrm{S}$ and $26^{0} 5^{\prime} \mathrm{S}$, and longitude $38^{\circ} 12^{\prime} \mathrm{E}$ and $38^{\circ} 7^{\prime} \mathrm{E}$. The elevation of the study area is 891 metres above sea level and the areal extent is $2422.5 \mathrm{Km}^{2}$ (Kithuka et al. 2018).

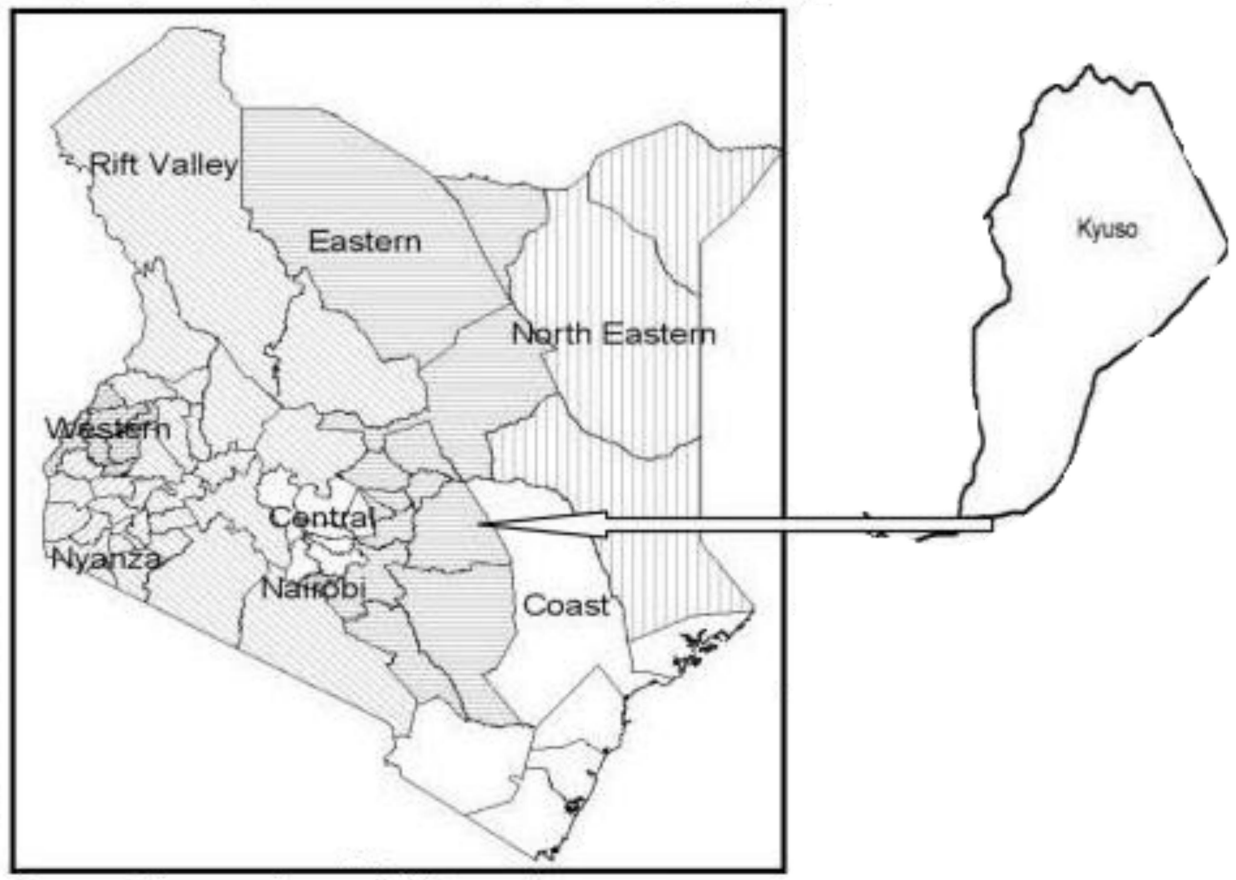

Figure 2.1: Location of Kyuso Sub-County in Kenya Source: Field survey, 2021

\subsection{Climate}

The study area lies in the arid and semi-arid climatic zone of Kenya (FAO-Sida 2012). There are two rainy seasons, March-May (Long rains) and October-December (Short rains). The mean annual rainfall ranges between 400 and $800 \mathrm{~mm}$ (Mwendwa 2014). However, the rainfall is unreliable, erratic and unpredictable (Maina 2012). The area is characterized by high temperatures throughout the year ranging between $26^{\circ} \mathrm{C}$ and $30^{\circ}$ C. The mean annual potential evaporation ranges between $2200 \mathrm{~mm}$ and $2400 \mathrm{~mm}$ (Mwendwa 2014).

\subsection{Drainage}

Drainage in this area is mainly influenced by River Tana, the only permanent river in the Sub-County. There are several seasonal rivers draining into Tana river including Kamuwongo, Tyaa and Thunguthu (Kitui County Integrated Development Plan (KCIDP) 2018).

\subsection{Soils}

The main soils in the study area include loamy sand soils, red sandy soils and black cotton soils (Maina 2012). Alluvial soils with moderate to high fertility are also common in river valleys (Mwendwa 2014). Hills are covered with stony soils that are thin and unsuitable for cultivation.

\subsection{Socio-economic activities}

Crop and livestock farming are the main economic activities in the study area. Drought resistant crops such as green grams, cow peas, maize, beans, sorghum, millet, cassava, sweet potatoes, pumpkins and pigeon peas are grown in every part of the Sub-County (KCIDP 2018). However, drought due to the unreliable and erratic rainfall mostly lead to crop failure (Mwendwa 2014). The main types of livestock kept include cattle, goats, donkeys and sheep (FAO-Sida 2012). Practices such as shifting cultivation and overgrazing have increased soil erosion rendering it unfertile.

\subsection{Water Resources}

There are several seasonal rivers that are characterized by flash flood flows during the wet season. Water holes and wells dug in the river beds are mostly saline (Maina 2012). There are also pans and earth dams that provide 
water for livestock farmers. The Kiambere-Mwingi water pipeline is the main source of fresh water to most of the residents living along the pipeline (Mwendwa 2014). Other water sources producing between 10 and $100 \mathrm{~m}^{3}$ daily are managed by community management committees (KCIDP 2018).

\section{Methodology}

\subsection{Research design}

Descriptive research design which involved pre-field work, review of relevant documents, fieldwork, collection, analysis and interpretation of data was employed in this study. Primary and secondary data were collected for this study. Primary data sources included data collected from households, government departments, non-state actors and other relevant departments. Secondary data was obtained from County Integrated Development plans, technical reports and journals.

\subsection{Data collection procedure}

Questionnaires were administered to hundred (100) households in the study area. The number was arrived at using Nassiuma (2000) formula (Equation 1).

$\mathrm{n}=\frac{N C v^{2}}{\left(C v^{2}+(N-1) e^{2}\right.}$ equation 1

Where $\mathrm{n}=$ sample size

$\mathrm{N}=$ population $(76,867)$

$\mathrm{Cv}=$ Coefficient of variation $(0.5)$

$\mathrm{e}=$ Tolerance of desired level of confidence, $0.05 \%$ at $95 \%$ confidence level

To ensure uniformity in the administration of the questionnaires, four transects were identified. The transects comprised of the four divisions in the Sub County, Ngomeni, Kyuso, Kamuwongo and Mivukoni. In each transect, simple random sampling was used to select 25 households to be included in the study. Interview schedules were used to collect data from local administrators, county water officers and the managers of different NGOs and CBOs providing water in the Sub-County.

\subsection{Data analysis and presentation}

Quantitative and qualitative techniques were used to analyse data collected from questionnaire survey. The collected data was coded using broad thematic areas, questions labelled and then analysed using Statistical Software for Social Sciences (SPSS) version 26. Excel was used to analyse questions with multiple responses. General inferences were made from percentages and proportions obtained from the analysed data. Frequency tables and graphs were used to present data.

\section{Results of the study}

\subsection{Performance of Non-State actors in provision of water}

It was established that Non-State actors have had a positive impact on the provision of water services in Kyuso Sub County. The study found out that access to safe drinking water has greatly improved with the establishment of CBOs. The results indicate that $68 \%$ of the respondents walk for less than one kilometres to access safe drinking water, $25 \%$ walk for $2-4$ kilometres while only $7 \%$ walk for more than 5 (five) kilometres (Figure 4.1 ). The study noted that the average distance that the residents travel to the nearest water point has reduced from 5 (five) kilometres to about 1 (one) kilometre. 


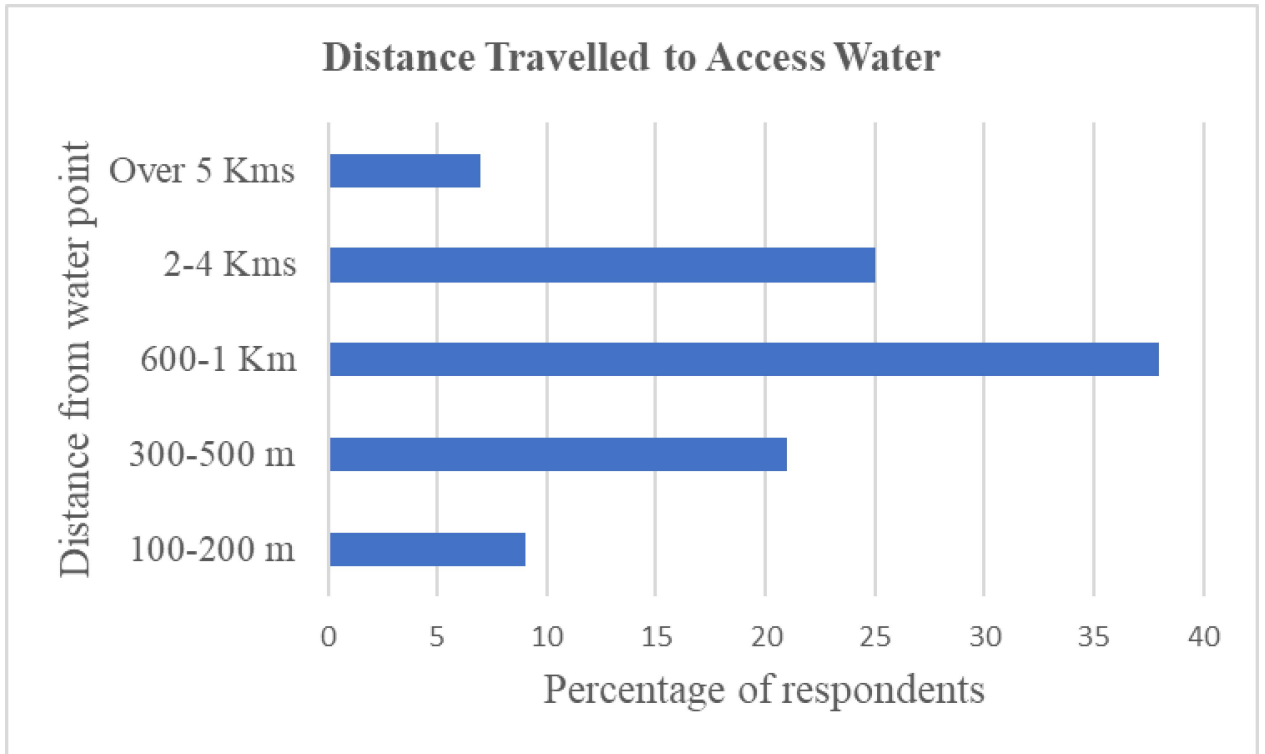

Figure 4.1 Distance travelled to access water in Kyuso Sub County Source: Field survey, 2020

\subsection{Frequency of piped water access}

The results indicate that most of the residents that rely on piped water supplied by Non-State actors only access that service twice a week. Only $7 \%$ of the respondents access piped water 7 (seven) days a week while $29 \%$ and $30 \%$ of the residents access water 3-4 days and 5-6 days a week, respectively (Figure 4.2). This could be attributed to the fact that, most of the non-state actors especially CBOs do not have adequate water storage facilities to guarantee water supply 7 days a week. The study also established that most of the water supply projects are established without proper engineering works and considerations. This leads to development of poor water infrastructure such as small diameter pipes that are not able to transport water for long distances.

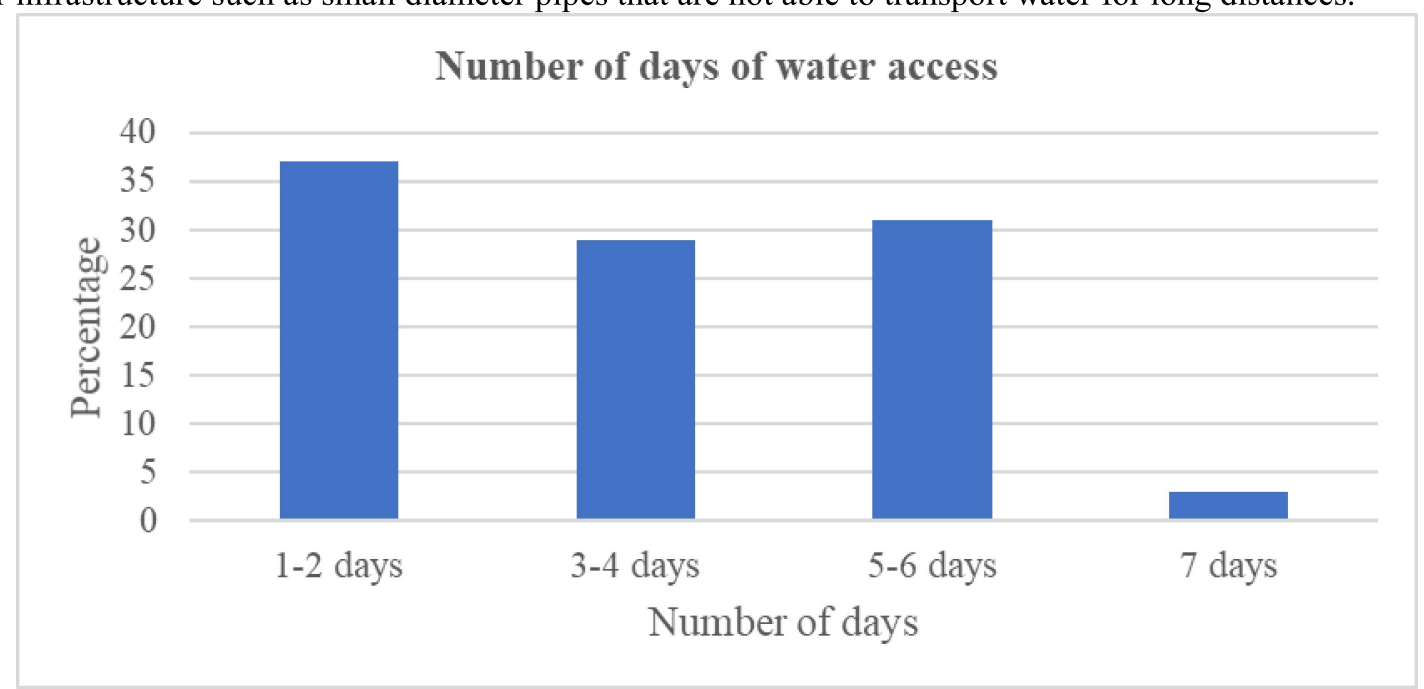

Figure 4.2: Number of days of water access Source: Field survey, 2020

\subsection{Challenges faced by Non-State actors in provision of water}

The study found out that Non-State actors face different challenges in providing water services in Kyuso SubCounty. The main problem that most of the Non-State actors face is poor management structures (Figure 4.3). This problem mainly arises since some of the $\mathrm{CBOs}$ are managed by individuals that have inadequate managerial skills. It was noted that some of the CBOs were started through the initiatives of NGOs such as Action Aid who transferred the managerial function to the community without training them on how to manage the projects. Poor management has resulted to dilapidated infrastructure such as old and leaking pipes that hamper water service delivery. Inadequate storage facilities that contribute to $15 \%$ of the challenges faced by Non-State actors can be attributed to the fact that most of the $\mathrm{CBOs}$ do not have adequate funding to construct or purchase storage tanks. 
Some of the available tanks have low storage volume which cannot serve the increasing population in the study area. The low and inadequate rainfall in the study area contribute $11 \%$ of the challenges faced by non-state actors. Low rainfall leads to drying up of water pans, earth dams, boreholes and wells constructed by Non-State actors to supply water to the residents of the study area. The unreliable nature of rainfall also leads to reduced volume of water in Kiambere dam which is the major source of piped water in the study area.

High connection fee, worn out infrastructure, uncooperative community and unregulated water tariffs account for $9 \%, 8 \%, 7 \%$ and $5 \%$ of the challenges facing non-state actors, respectively. High connection fee that residents are required to pay to get connection to their homes often discourage them from getting connected to the water pipeline. This makes some of the residents walk for long distance to access water services. Some of the community members, especially those that are not part of the CBOs interfere with the water infrastructure making their replacement expensive. The Non-State actors are not regulated in setting the tariffs for their water services. This makes some of them charge high fees that some of the residents cannot afford. With regard to worn out infrastructure, the study established that some of the pipes used are made of material such as plastic that wear out after a short period due to the intensity of sun's radiation in the area. In addition, some pipes also burst since their diameter cannot withstand the pressure when water is pumped from Kiambere dam.

\section{Challanges faced by Non-State Actors}

Inadequate storage facilities

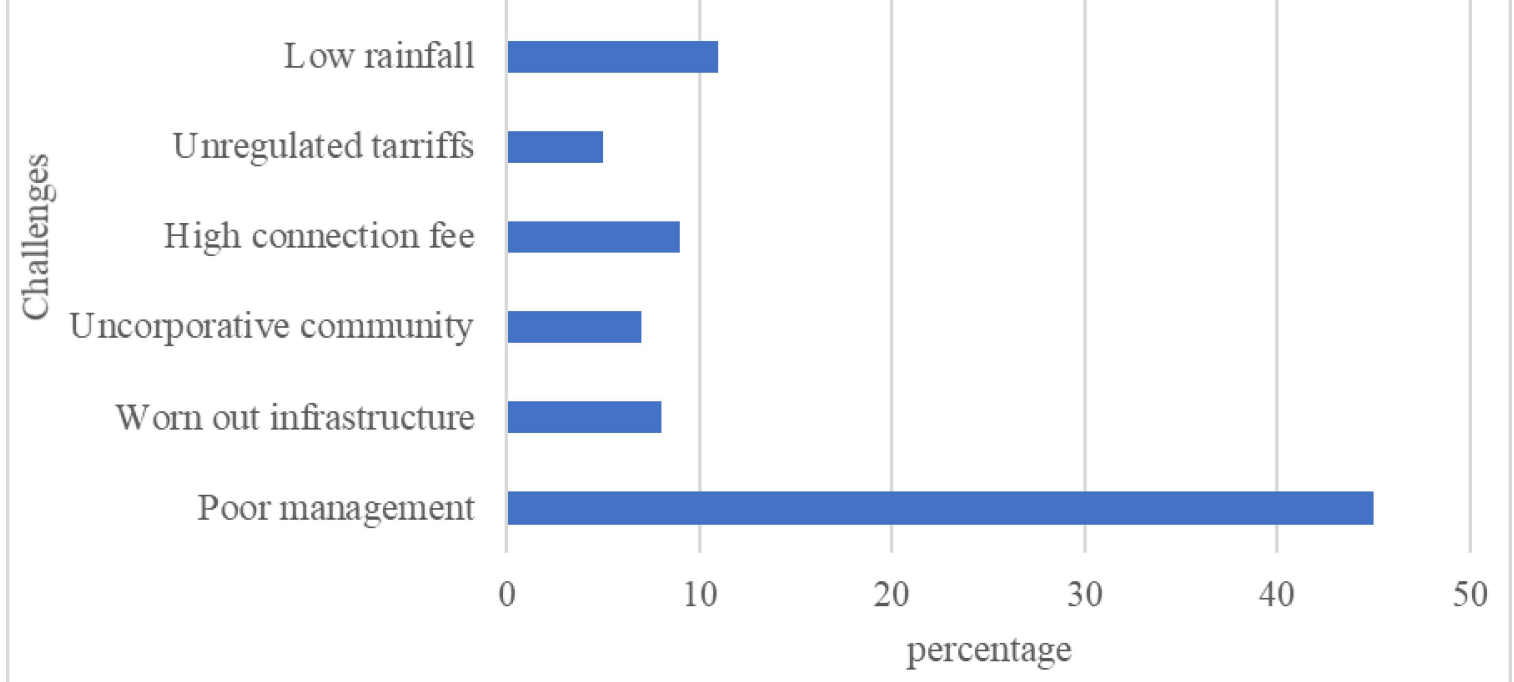

Figure 4.3: Challenges faced by Non-State actors in provision of water in Kyuso Sub-county Source: Field survey, 2020

\subsection{Measures to improve performance of Non-State actors in water service provision}

The study established that improving management structure of the Non-State actors was the most recommended measure $(25 \%)$ to improve water service delivery (Table 4.1 ). The managers of these organizations need to be trained on how to manage projects and funds received from the billing of water services. Some respondents, $21 \%$, also believe that improving water infrastructure could improve water service delivery by non-state actors. This could involve hiring qualified water engineers to conduct surveys before the commencement of the water projects, repair of broken water pumps, desilting of earth dams and water pans and installation of larger water storage tanks. Equitable distribution of water, establishment of more CBOs and enhanced public participation accounted for $17 \%, 20 \%$ and $17 \%$, respectively of the responses. Improving equity in the supply of water by Non-State actors will enable most of the residents appreciate the importance of the projects thus reduce the instances of vandalism of the water infrastructure. On the other hand, having more CBOs could ensure more areas that are not covered by the current water supply projects are supplied with water. Enhancing public participation could help mitigate some of the challenges including vandalism of water infrastructure while also enhancing viability of the water supply projects. 
Table 4.1: Measures to improve performance of Non-State actors

\begin{tabular}{lc}
\hline Recommendation & Percentage of respondents \\
\hline Improve management structure & $25 \%$ \\
\hline Ensure equity in distribution & $17 \%$ \\
\hline Improve infrastructure & $21 \%$ \\
\hline Establish more CBOs & $20 \%$ \\
\hline Enhance public participation & $17 \%$ \\
\hline Total & $100 \%$ \\
\hline
\end{tabular}

Source; Field Survey, 2020

\section{Discussions}

\subsection{Performance of Non-State actors in provision of water}

The study established that Non-State actors have greatly reduced the distance that residents travel to access water services to less than one kilometre. These results agree with Kifanyi et al. (2013) who found out that the establishment of community water supply project in Hanna Nassif settlement area in Tanzania had greatly improved water supply in the area. The authors also indicated that the commencement of the water supply project also reduced the distance to the water points since most of the people were fetching water within the settlement. Similarly, Sun et al. (2010) reported that non-governmental organizations and private sector contributed to water supply in rural Ghana by drilling boreholes and other water supply schemes. In addition, Community Water Initiatives (2013) established that community-based water supply schemes look at the opportunities and challenges facing the community with regard to water supply. Engel et al. (2005), found out that Non-governmental organizations and private sector participate in improving water service provision through construction and maintenance of water infrastructure.

\subsection{Frequency of piped water access}

The results of this study indicated that most of the residents of Kyuso Sub-County who rely on piped water supply from Non-State actors only access water for only two days in a week. This can be attributed to the fact that the Non-State actors' pipelines are reliant on public water supply scheme on Kiambere-Mwingi water pipeline. These findings are similar to Kifanyi et al. (2013) who established that water supply by Hanna Nassif Community Development Association depended on the water supply from the main public water supply pipe. Failure by the main public water supply pipeline leads to inadequate water supply by Non-State actors. The unreliability of water supply could also be attributed to the high seasonal rainfall variability in the study area. Nyaga (2019) established that the reliability of water supply in Kitui County was affected by inadequate rainfall in the county.

\subsection{Challenges faced by Non-State Actors}

Poor management structure was cited as the main challenge facing Non-State actors in the provision of water services in Kyuso Sub-County. This problem mainly arises from the fact that most of the managers do not have formal training on management. Similar findings were reported by Kifanyi et al. (2013) that most of the managers of Hanna Nassif project did not have financial management abilities of recording and reporting. Similarly, Maina (2014) observed that inadequacies in funding hampered the performance of NGO's in the provision of water services in Huruma estate, Nairobi. Cheruiyot (2016) also noted that project management skills were important in the success of Community Based Water Projects. Further, the author observed that training on project management, developing a clear work plan and carrying out monitoring and evaluation of the project contributed to the success of such projects.

This study also noted that inadequate stakeholder participation was hindering the performance of Non-State actors in the provision of water services in Kyuso Sub-County. This affects the acceptance of the projects and leads to vandalism of the water infrastructure in some of the areas. This agrees with Argawa (2001) who found out that community involvement in any projects ensures strong support for the project that leads to strong performance. Similarly, Freeman (2001) reported that project managers need to gain the support of stakeholders in order to achieve the organizations objectives. Additionally, Davids (2009) found out that involvement of community in development projects builds the capacity and empowers the community which enables efficiency in the process of identifying, monitoring and evaluating a project. In their study Engel et al. (2005) established that charging a fee per bucket negatively influenced decision making with regard to access of improved water sources and quantity of improved water used.

\subsection{Measures to improve performance of Non-State Actors in provision of water services}

The study established that improving management structure of the community based organizations could improve their performance in providing water services in Kyuso Sub-County. Improving public participation and 
ensuring equity in the distribution of water services could also improve reliability of the water services. The results concur with Kartz and Sara (1997) who noted that there was a strong link between household member's participation and sustainability of water projects. Similarly, Isham and Kahkonen (2002), established that involving community members in the designing and executing a project contributes to its success. Cleaver (1999) found out that community empowerment and the approaches to enhance effective participation was a complex process. The author noted that mobilizing necessary resources either from government departments or lobbying community members was not enough since problems in management of community water projects still persisted.

\section{Conclusions}

This study concluded that Non-State actors have improved water service provision in Kyuso Sub-County. The distance to the nearest water point has greatly reduced since Non-State actors have established more water points in the area. However, most of the residents only access piped water twice a week. The Non-State actors face several challenges in providing water including poor management structures, inadequate storage facilities, low and unreliable rainfall, worn out infrastructure and high connection fees. The worn out pipes take long before they are replaced due to the inadequate funds. To improve water service provision, Non-State actors should improve public participation structures. This will ensure the residents appreciate the projects and reduce vandalism of water infrastructure. Non-State actors should also invest in training managers to improve management structures and prudent management of funds. The County government should also ensure there is frequent supply of water from Kiambere-Mwingi water pipeline since most of the Non-State actors rely on the pipeline to supply water. The Non-State actors should also invest in storage tanks to ensure there is enough water even when there is insufficient supply from Kiambere-Mwingi pipeline.

\section{References}

Argawa, B. (2001). Participatory Exclusions, Community Forestry and Gender: An Analysis for South Asia and Conceptual Framework. World Development 29(10), 1623-48

Cheruiyot, S. (2016). Factors influencing performance of community based water projects in Bomet County. $A$ research project report submitted in partial fulfillment of the requirements for the award of Master of Arts Degree in Project Planning and Management of University of Nairobi.

Cleaver, F. (1999). Paradoxes of participation: Questioning participatory approaches to development. Journal of International Development 11: 567-612.

Community Water Initiative (2013). Creating Community-Based Water and Sanitation Schemes to Improve Food Security, Livelihoods and Resource Conservation

Davids, I. (2009). Participatory development in South Africa: A Development Management Perpective. Pretoria: Van Schaik.

Eberhard, R., (2019). Access to Water and Sanitation in Sub-Saharan Africa. Eschborn, GIZ.

Engel, S., Iskandarani, M., and Useche, M. (2005). Improved water supply in the Ghanaian Volta basin: Who uses it and who participates in community decision-making? Environment Production, and Technology Division Discussion Paper 129. Washington, D.C.: International Food Policy Research Institute

FAO-Sida (2012). Improve Livelihoods in Targeted Drought Affected Communities in Kenya OSRO/KEN/002/SWE (final report). Nairobi, FAO-KE

Freeman, R., and McVea, J. (2001). A Stakeholder Approach to Strategic Management. Accessed from https://ssrn.com/abstract $=263511$ on $14^{\text {th }}$ June, 2021 .

Isham, J., and Kahkonen. (2002). Institutional determinants of impact of community-based water services: Evidence from Sri Lanka and India. Middlebury College Economics Discussion Paper No. 02-20. Middlebury, Vt; Middlebury College, Department of Economics

Katz, T., and J. Sara, J. (1997). Making rural water supply sustainable: Recommendations from a global study. Accessed from htttp://www.wsp.org/UserFiles/file/global_ruralstudy.pdf on 14 ${ }^{\text {th }}$ June, 2021.

Kifanyi, G., Shayo, B., and Ndambuki, J. (2013). Performance of community based organizations in managing sustainable urban water supply and sanitation projects. International Journal of Physical Science Vol. 8(30), pp. 1558-1569.

Kithuka, P., Kanui, T., and Kimiti, J. (2018). Household Demographics and Income Losses in Kyuso Sub County of Kitui County. International Journal of Education and Research.

Kitui County Integrated Development Plan (2018). County Integrated Development Plan 2018-2022. Nairobi; Government Printer.

KNBS (2019). 2019 Kenya Population and Housing Census Results. Kenya National Bureau of Statitistics. Accessed from https://www.knbs.or.ke

Maina, G. (2012). Kyuso and Mulangoni Baseline Survey Report. Ministry of Livestock Development

Maina, K. (2010). Assessment of the Challenges of Water Supply and Sanitation in Uncontrolled Residential Developments of Huruma Estate, Nairobi County. Research Project Submitted in Partial Fulfillment for the 
Requirement for the Award of Bachelor Degree in Environmental Planning and Management of Kenyatta University.

Munyui, E. (2015). Factors Influencing Sustainability of Community Water Projects: A Case of Kitui West Subcounty, Kitui County. A research Project Report Submitted in Partial Fulfilment for Award of Degree of Master of Arts, University of Nairobi.

Mwendwa, P. (2014). Performance of Non-State Actors in Provision of Water along Kiambere-Mwingi Water Pipeline in Kamuwongo Division, Kitui County. A Research Project Submitted in Partial Fulfillment for Degree of Master of Environmental Planning and Management in the School of Environmental Studies of Kenyatta University.

Nassiuma, D. (2000). Survey Sampling Theory and Methods. Nairobi; Nairobi University Press.

Nyaga, C. (2019). A Water Infrastructure Audit of Kitui County. University of Oxford http://www.ox.ac.uk/

Sun, Y., Asante, F., and Birner, R. (2010). Opportunities and Challenges of Community-Based Rural Drinking Water Supplies: An Analysis of Water and Sanitation Committees in Ghana. IFPRI Discussion Paper 01026

UNESCO, UN-WATER (2020). United Nations World Water Development Report: Water and Climate Change. Paris; UNESCO.

UNICEF Kenya (2020). Improving children's access to water, sanitation and hygiene. Nairobi, UNICEF.

United Nations (2015). Sustainable Development Goals. United Nations. Accessed from https://www.un.org/sustainabledevelopment on June 3, 2021.

USAID (2019). Ensuring Access to Water in Kenya. Accessed from https://www.reliefweb.int/report/kenya on June 5, 2021.

World Health Organization; UN-Water (2014). WHO/UN-Water GLAAS 2014 Report. UN Glass. https://doi.org/9789241508087. 